\title{
Limitations to photosynthesis of leaves of apple (Malus domestica) trees across the growing season prior to and after harvest
}

\author{
D.H. GREER \\ National Wine and Grape Industry Centre, School of Agricultural and Wine Sciences, Charles Sturt University, \\ Locked Bag 588, Wagga Wagga, NSW, Australia
}

\begin{abstract}
Photosynthetic responses to $\mathrm{CO}_{2}$ were followed on leaves of Malus domestica cv. Cox's Orange trees growing in orchard conditions, before and after harvest. Rates of photosynthesis, at ambient and $\mathrm{CO}_{2}$ saturated concentrations, were stable across the growing season, except for minor decreases at harvest although rates recovered and remained high thereafter. Stomatal conductance increased over the growing season but declined transiently just before harvest and recovered for most of the season. Rates of ribulose-1,5-bisphosphate (RuBP) carboxylation declined before harvest, however, rates of RuBP regeneration mirrored assimilation. After harvest, rates of RuBP regeneration increased whereas rates of carboxylation increased but remained low, limiting photosynthesis. Lack of change in photosynthesis after harvest was at odds with the literature where photosynthesis of high crop load trees declined soon after, suggesting crop load was not as demanding on the Cox's Orange trees as in other studies.
\end{abstract}

Additional key words: $\mathrm{CO}_{2}$ response; gas exchange; nonstomatal limitation; post-harvest; pre-harvest; stomatal limitation.

\section{Introduction}

It has become well established that fruiting trees have relatively high rates of photosynthesis (Avery 1977). For example, Wünsche et al. (2000) showed for cv. Braeburn apple trees that those without fruit ranged in photosynthesis from 3-7 $\mu \mathrm{mol} \mathrm{m} \mathrm{m}^{-2} \mathrm{~s}^{-1}$ over selected days. By contrast, trees with a full crop load had photosynthetic rates ranging from $11-14 \mu \mathrm{mol} \mathrm{m} \mathrm{m}^{-2} \mathrm{~s}^{-1}$ during the sample period. Similar results were observed with cv. Golden Delicious (Gucci et al. 1995, Wibbe and Blanke 1995, 1997) and sweet cherry (Quentin et al. 2013). More specifically, Palmer et al. (1997) demonstrated that photosynthesis increased in a curvilinear pattern with increasing crop load, thus confirming the strong conclusion that a high sink demand enhanced the photosynthetic capacity of the fruit trees. As a corollary of this response, harvest of the fruit generally results in crop load-induced differences in photosynthesis dissipating within 10-20 days (Palmer et al. 1997, Wünsche et al. 2000). Furthermore, the decreases in photosynthesis were most marked in the trees with the higher crop loads and least marked on those trees without fruit. However, the effect of the fruit harvest on photosynthesis through the remainder of the growing season has not been well investigated.

The general assumption for the decrease in photosynthesis after a large crop load has been removed is a consequence of a loss of sink capacity (Herold 1980). This is despite the fact that deciduous horticultural species rely heavily on storing carbohydrates in root reserves for the subsequent bud-break processes in the following spring (Kandiah 1979, Greer et al. 2002, Holzapfel et al. 2010) and would expect to be a large sink (Palmer et al. 1997). Consistent with this hypothesis, for evergreen sweet orange trees (Nebauer et al. 2013), crop load had no marked effect on photosynthesis and there were also no seasonal changes in photosynthesis. Similarly, a comparison of summer and winter photosynthetic rates of sweet orange trees indicated reduced winter rates were a consequence of cold nights (Ribeiro et al. 2009) and not consequent upon the harvest. For deciduous fruit trees, therefore, it may take some time for the trees to establish the increased demand by the roots and thus measurements up to leaf fall may be required.

Another possibility for the decrease in photosynthesis after harvest may relate to either increased stomatal or nonstomatal, that is biochemical, limitations. The stomatal

$\overline{\text { Received }} 2$ August 2018, accepted 21 November 2018.

Phone: +61 26933 2725, e-mail: dgreer@csu.edu.au

Abbreviations: $A_{\mathrm{c}}$ - modelled rates of carboxylation; $A_{\mathrm{j}}$ - modelled rates of electron transport; $C_{\mathrm{a}}-$ ambient $\mathrm{CO}_{2}$ concentration; $C_{\mathrm{i}}-$ internal $\mathrm{CO}_{2}$ concentration; DAB - days after bud break; $E$ - transpiration; $g_{\mathrm{s}}$ - stomatal conductance; $J_{\max }-$ maximum rate of RuBP regeneration; $P_{\mathrm{N}}-$ net photosynthetic rate; $P_{\mathrm{Nmax}}-$ light- and $\mathrm{CO}_{2}$-saturated photosynthesis; $R_{\mathrm{d}}-$ day respiration rate; RuBP - ribulose1, 5-bisphosphate; $V_{\text {cmax }}$ - maximum rate of RuBP carboxylation.

Acknowledgements: My thanks to Professor Jens Wünsche for continuing a long-standing collaboration and hosting my visit and supplying the facilities and equipment to undertake this research. I also thank the staff at the Department of Specialty Crops for assisting with maintaining the equipment and some good conversations. This project was undertaken while the author was on Special Studies and funded by Charles Sturt University with a grant to travel and work at the Universität Hohenheim. I also thank the referees for their suggestions. 
limitation of photosynthesis, originally proposed by Farquhar and Sharkey (1982; see also Jones 1985), varied progressively over the growing season for $\mathrm{cv}$. White Riesling grapevines from about $60 \%$ at the start to about $25 \%$ at harvest time (Schultz et al. 1996). For two apple cultivars, including cv. Golden Delicious and cv. Granny Smith, the stomatal limitation from early in the growing season (33 d after bud break, DAB) ranged from 16 to $18 \%$ and peaked at 25 and $19 \%$, respectively, in midsummer (100 DAB) before declining to 22 and $8 \%$ in autumn (145 DAB) (Mierowska et al. 2002). Other evidence has shown the stomatal limitation can vary with temperature, varying from 13 to $34 \%$ between 20 and $40^{\circ} \mathrm{C}$ for Semillon grapevines (Greer and Weedon 2012) and from 25 to $63 \%$ between 15 and $40^{\circ} \mathrm{C}$ for cv. Red Gala apple trees (Greer 2015). For two oak species (Quercus ilex and Q. faginea) grown in a Mediterranean climate with mean summer temperatures of $21-22.5^{\circ} \mathrm{C}$, the stomatal limitation ranged from 25 to $35 \%$ (Juárez-López et al. 2008). For the grapevine cultivar cv. Aragonez, grown in conditions where air temperatures reached $33^{\circ} \mathrm{C}$ during the day, the stomatal limitation aver-aged $22 \%$. There appears to be few determinations of the stomatal limitation in the postharvest period of fruiting trees. However, for two sweet cherry cultivars, cv. Kordia and cv. Sylvia, grown in a cool climate (summer maximum $22.5^{\circ} \mathrm{C}$ ), the stomatal limitation, six weeks after harvest, ranged from $13-16 \%$ (Quentin et al. 2013) but it remains uncertain if this was a post-harvest effect or a cool climate influence. In contrast, for the evergreen sweet orange trees grown in Brazil with warm summers $\left(30-33^{\circ} \mathrm{C}\right)$ and winters $\left(25-29^{\circ} \mathrm{C}\right)$, the stomatal limitation varied from $40 \%$ in winter to $60 \%$ in summer, in keeping with other studies on trees grown in warm to hot climates.

There have also been seasonal determinations of the changes in the nonstomatal limitations, including the maximum rates of carboxylation $\left(V_{\text {cmax }}\right)$ of ribulose 1, 5-bisphosphate (RuBP) and the maximum rates of RuBP regeneration $\left(J_{\max }\right)$. For example, Greer (2015) followed both limitations on leaves of apple trees grown in a hot climate and demonstrated that $V_{\mathrm{cmax}}$ and $J_{\max }$ were both high in spring and declined through summer with high temperatures although did recover late in the season, when air temperatures were reduced. A similar pattern in $V_{\text {cmax }}$ and $J_{\max }$ occurred with grapevines cv. Chardonnay and cv. Merlot, in that both declined progressively through the growing season (Greer 2017), see also Schultz (2003) for similar effects on Riesling vines. A similar pattern was also shown with Quercus douglasii trees grown in a similarly hot climate, although there was an initial increase in both $V_{\text {cmax }}$ and $J_{\max }$ after bud break (Xu and Baldocchi 2003). In contrast, the maritime pine, Pinus pinaster, had the highest $V_{\text {cmax }}$ and $J_{\max }$ in mid-winter and lowest rates in summer (Medlyn et al. 2002). For Pinus ponderosa growing in the Sierra Nevada, both $V_{\text {cmax }}$ and $J_{\max }$ increased from spring to peak in summer as did an understory evergreen shrub Ceanothus cordulatus, although $V_{\mathrm{cmax}}$ and $J_{\max }$ peaked later in early autumn (Misson et al. 2006). Similar patterns were also noted for several different Eucalyptus species (Lin et al. 2012). Although $V_{\text {cmax }}$ and $J_{\max }$ have been measured in several fruit tree species, including Juglans regia (Le Roux et al. 1999), Prunus persica cv. Fantasia and peach (Rosati et al. 1999, Walcroft et al.2002), and Olea europaea (DíazEspejo et al. 2006), there have been few other seasonal evaluations other than those listed above. However, $V_{\text {cmax }}$ and $J_{\max }$ were measured at a set time after the harvest of sweet cherries but only once (Quentin et al. 2013). Thus, there is a poor understanding of the changes that might occur in $V_{\text {cmax }}$ and $J_{\max }$ limitations of $\mathrm{CO}_{2}$ assimilation after the removal of the fruit sink.

Accordingly, the hypothesis that apple leaf photosynthesis would decline after the fruit harvest through a reduction in sink capacity was assessed. This was evaluated by measuring the seasonal changes in gas exchange and the response to internal $\mathrm{CO}_{2}$ of leaves of Cox's Orange apple trees growing in orchard conditions, both prior to and after harvest. A second objective was to assess the stomatal and nonstomatal limitations to assimilation as the season progressed.

\section{Materials and methods}

Growth conditions: This study was conducted at the Research Orchard of the Universität Hohenheim, Stuttgart, Germany, located at latitude of $48^{\circ} 42^{\prime}$, longitude of $9^{\circ} 12^{\prime}$, and an altitude of $390 \mathrm{~m}$ a.s.1. The 10-year-old apple trees (Malus domestica cv. Cox's Orange) were grafted onto M9 rootstocks and planted in $3-\mathrm{m}$ rows at a spacing of $2 \mathrm{~m}$ between trees. The trees were not irrigated but regular rainfall occurred throughout the growing season. Bud break and flowering typically occurred about mid-April and the trees were harvested in mid-September. Six trees were randomly selected and all trees held a moderate crop load (Wünsche, personal communication). All measurements were undertaken on selected fruiting shoots on each tree and all leaves were fully expanded and remained visually green throughout the measurement period, without any signs of senescence.

The site microclimate was monitored nearby within the orchard and air temperature and light intensity were monitored at hourly intervals throughout each day of the growing season.

Leaf gas exchange was monitored with an open gas-exchange system and PLC5 automatic leaf cuvette (Cirras-1, $P P$ Systems, Hitchin, UK) and included use of the LEDbased lighting system (CRS131, PP Systems, Hitchin, UK). Leaf temperature and photon flux density were measured concurrently for each leaf with the system. Photosynthesis $\left(P_{\mathrm{N}}\right)$, stomatal conductance $\left(g_{\mathrm{s}}\right)$, and transpiration $(E)$ were monitored on representative leaves of bourse shoots. Photosynthetic measurements were conducted from late July until late October.

$\boldsymbol{P}_{\mathrm{N}} / \boldsymbol{C}_{\mathrm{i}}$ responses: Measurements of the photosynthetic response to internal $\mathrm{CO}_{2}$ concentrations $\left(C_{\mathrm{i}}\right)$ were undertaken on selected days prior to harvest using the open gasexchange system. In each case, fully expanded leaves of each of selected shoots were at a constant saturating PFD of $1,500 \mu \mathrm{mol} \mathrm{m} \mathrm{m}^{-2} \mathrm{~s}^{-1}$. The temperatures were not controlled 
and generally increased through the day in keeping with the ambient condition but ranged between 20 and $30^{\circ} \mathrm{C}$. After harvest, the ambient temperatures were too low to allow a range of temperatures to be measured, therefore, all gas-exchange measurements were monitored at a constant $20^{\circ} \mathrm{C}$. The measurement protocol throughout included measuring the rate of photosynthesis at an ambient $\mathrm{CO}_{2}$ concentration $\left(400 \mu \mathrm{mol} \mathrm{mol}^{-1}\right)$ and then the intercellular $\mathrm{CO}_{2}$ concentration was reduced to about $30-50 \mu \mathrm{mol} \mathrm{mol}^{-1}$ and the rates measured and then the $\mathrm{CO}_{2}$ concentrations were progressively increased to about $1,200-1,400 \mu \mathrm{mol} \mathrm{mol}^{-1}$ and rates measured in 100-200 $\mu \mathrm{mol} \mathrm{mol}^{-1}$ steps. For each day, the $P_{\mathrm{N}} / C_{\mathrm{i}}$ responses were repeated 10-12 times on a new leaf on each occasion.

Data analysis: All $P_{\mathrm{N}} / C_{\mathrm{i}}$ data were analysed statistically using a general linear modelling (GLM) approach with SAS ver. 9.1.3 (SAS Institute, Cary, NC, USA), assuming a completely randomised design. Least squares means and standard errors were determined. The data were analysed in $S A S$ (SAS Institute) using nonlinear regression according to the Farquhar et al. (1980) $\mathrm{C}_{3}$ model of photosynthesis, following the equations described by Medlyn et al. (2002) and adopted by Greer and Weedon (2012), however, using the kinetic constants of Sharkey et al. (2007). Firstly, the maximum rates of ribulose-1,5-bisphosphate carboxylation $\left(\mathrm{RuBP}, V_{\text {cmax }}\right)$ and the day respiration rates $\left(R_{\mathrm{d}}\right)$ were determined with $S A S$ for $C_{\mathrm{i}}<200 \mu \mathrm{mol} \mathrm{mol} \mathrm{m}^{-1}$. The second step involved using the previously established estimates for day respiration and the maximum rates of RuBP regeneration were determined with $S A S$ for $C_{\mathrm{i}}>$ $250 \mu \mathrm{mol} \mathrm{mol}{ }^{-1}$, following the procedure of Silim et al. (2010). For each $P_{\mathrm{N}} / C_{\mathrm{i}}$ curve, the stomatal limitation was also determined according to the method of Farquhar and Sharkey (1982) and described by Greer and Weedon (2012). To evaluate the seasonal changes in all parameters, a GLM approach was used to assess the main effect of day across the whole season on photosynthesis, stomatal conductance, transpiration as well as $V_{\text {cmax }}$ and $J_{\max }$. In addition, the model also assessed if these parameters were correlated with the mean daily maximum and minimum air temperatures and photon flux densities.

\section{Results}

Climate across the growing season: At the start of measurements in early summer (Fig. $1 A$ ), the maximum daily PFDs generally averaged 1,200-1,400 $\mu \mathrm{mol} \mathrm{m} \mathrm{m}^{-2} \mathrm{~s}^{-1}$ although there were cloudy days when the PFDs were below about $800 \mu \mathrm{mol} \mathrm{m}^{-2} \mathrm{~s}^{-1}$. By late summer, the maximum daily PFDs were declining progressively, such that by the end of measurements, the PFDs were below about $400 \mu \mathrm{mol}$ $\mathrm{m}^{-2} \mathrm{~s}^{-1}$.

The mean daily maximum and minimum air temperatures (Fig. $1 B$ ) followed a similar pattern to the PFDs, with the highest mean daily temperatures over summer averaging between 20 and $25^{\circ} \mathrm{C}$ and the mean minimum temperatures averaging between 10 and $15^{\circ} \mathrm{C}$. The decrease in temperatures also occurred coincident with the decrease in PFD and the maximum temperatures declined

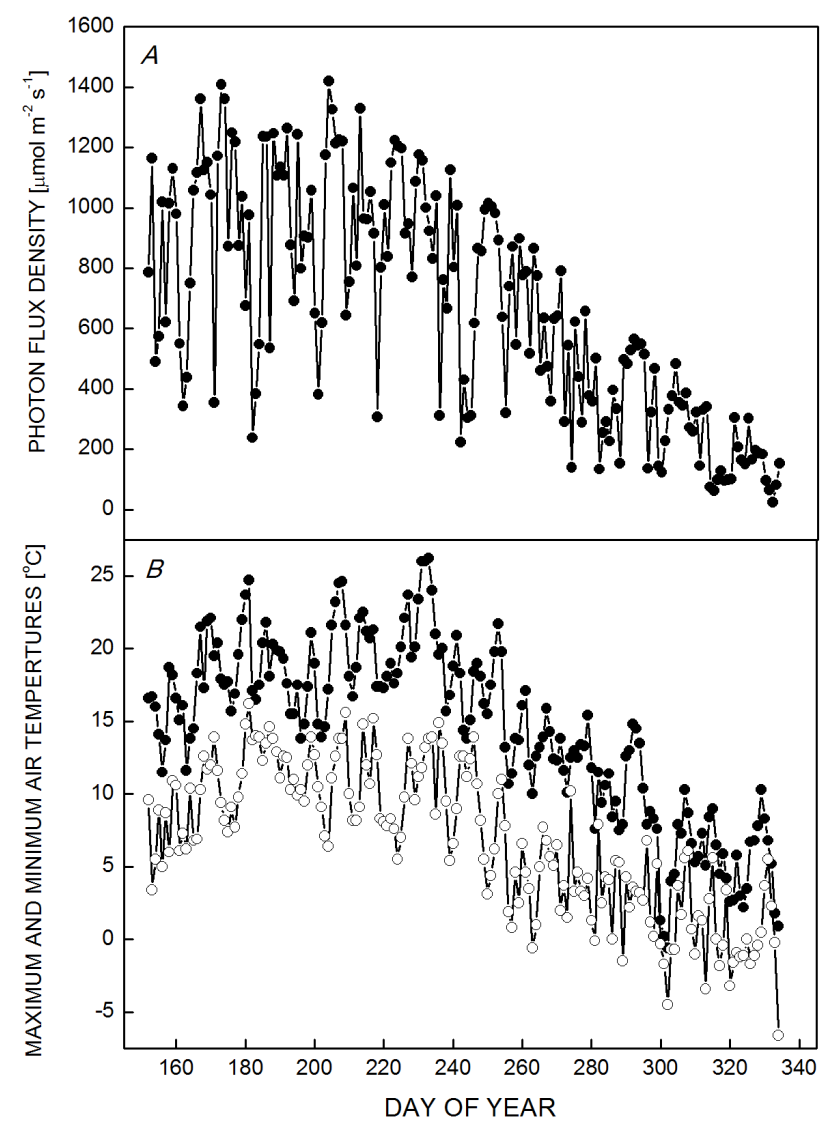

Fig. 1. Seasonal changes in mean daily photon flux density $(A)$ and the mean daily maximum (closed symbols) and minimum (open symbols) air temperatures $(B)$ measured at the Universität Hohenheim orchard nearby to where the trees where growing. Harvest occurred on day 265 (22 September).

from about 20 to $10^{\circ} \mathrm{C}$ when measurements finished. At the same time, the daily minimum temperatures declined from about 8 to $2^{\circ} \mathrm{C}$ and close to $0^{\circ} \mathrm{C}$ on occasions.

Seasonal changes in gas exchange pre- and post-harvest: Mean light-saturated rates of photosynthesis at ambient $\mathrm{CO}_{2}$ concentrations across the season prior to harvest were relatively constant at about $14-16 \mu \mathrm{mol} \mathrm{m} \mathrm{m}^{-2} \mathrm{~s}^{-1}$ although a few days before harvest, the rates had declined to about $10-12 \mu \mathrm{mol} \mathrm{m}^{-2} \mathrm{~s}^{-1}$ (Fig. $2 A$ ). After harvest, there was a recovery of the rates to again average 14-16 $\mu \mathrm{mol}$ $\mathrm{m}^{-2} \mathrm{~s}^{-1}$ although there was a subsequent slight decrease over the season, such that by the last measurements, the rates averaged $12 \mu \mathrm{mol} \mathrm{m} \mathrm{m}^{-2} \mathrm{~s}^{-1}$ (Fig. $2 B$ ). These results might have occurred from low PFDs about the time of harvest which caused the short-term downregulation of photosynthesis as the PFDs increased and the rates had recovered a few days after harvest. Across the season, there was a significant $(P<0.001, n=26)$ effect of day on photosynthesis, but was relatively weak, only accounting for $15 \%$ of the variance. There was, however, no correlation between light-saturated photosynthesis and the seasonal climate.

By contrast, the mean stomatal conductance prior to 


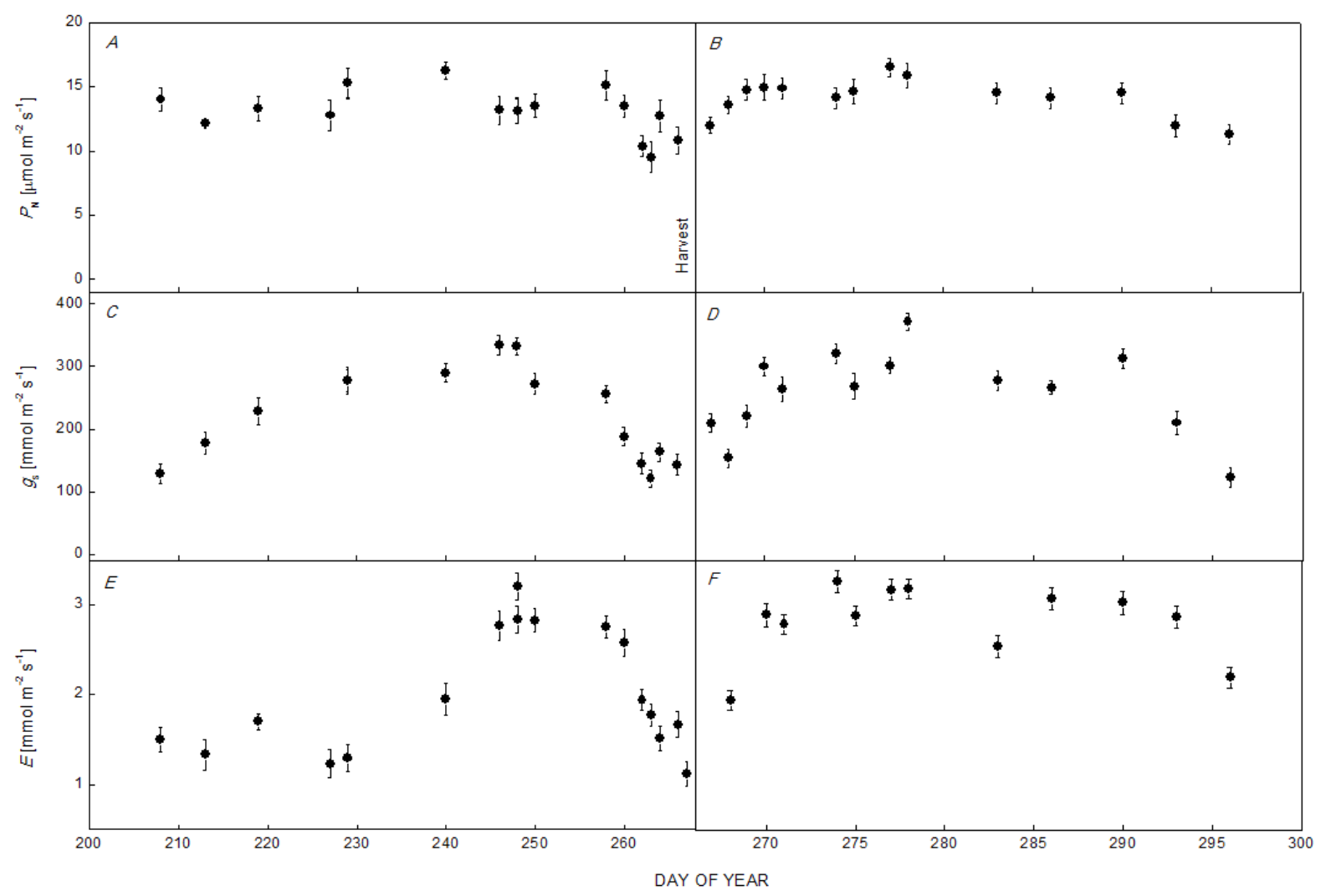

Fig. 2. Seasonal changes in light-saturated net photosynthesis (mean $\pm \mathrm{SE}, n=9-12)$ before $(A)$ and after $(B)$ harvest, stomatal conductance before $(C)$ and after $(D)$ harvest, and transpiration before $(E)$ and after $(F)$ harvest for leaves of Cox's Orange apple trees growing in orchard conditions. Harvest occurred on Day 265 as indicated. The average leaf temperature during the pre-harvest period was $26.8^{\circ} \mathrm{C}$ and the average ambient $\mathrm{CO}_{2}$ concentration was $409 \mu \mathrm{mol} \mathrm{mol}^{-1}$ and during the post-harvest period, the average leaf temperature was $20.9^{\circ} \mathrm{C}$ and the average ambient $\mathrm{CO}_{2}$ concentration was $400 \mu \mathrm{mol} \mathrm{mol}^{-1}$. A snow storm in late October curtailed any more measurements.

harvest increased across the growing season to peak at $330 \mathrm{mmol} \mathrm{m}^{-2} \mathrm{~s}^{-1}$ at about the end of summer (Fig. 2C). Thereafter, the conductance declined, such that just at harvest, averaged $150 \mathrm{mmol} \mathrm{m} \mathrm{m}^{-2} \mathrm{~s}^{-1}$. After harvest, the stomatal conductance increased again to about $300 \mathrm{mmol}$ $\mathrm{m}^{-2} \mathrm{~s}^{-1}$ and remained more or less constant until the end when there was an indication of some stomatal closure (Fig. 2D). There was a significant effect of day on the stomatal conductance and this accounted for nearly $50 \%$ of the variance but there was no correlation with the seasonal climate.

Transpiration followed yet a different pattern prior to harvest, with rates remaining low and relatively constant at $1.5 \mathrm{mmol} \mathrm{m}^{-2} \mathrm{~s}^{-1}$ over the early and midsummer but the rates increased markedly at the end of summer to about $3 \mathrm{mmol} \mathrm{m}^{-2} \mathrm{~s}^{-1}$ (Fig. 2E). Thereafter, there was a decrease in rates of transpiration that conformed closely to the decrease in stomatal conductance. During the season after harvest, the rates of transpiration initially increased but, for the most part, remained about constant at 2.5-3 mmol $\mathrm{m}^{-2} \mathrm{~s}^{-1}$ (Fig. $2 F$ ). There was a significant effect of day on the transpiration and this accounted for nearly $40 \%$ of the variance but again there was no correlation with the seasonal climate.
$\boldsymbol{P}_{\mathrm{N}} / \boldsymbol{C}_{\mathrm{i}}$ responses pre- and post-harvest: Typical $P_{\mathrm{N}} / C_{\mathrm{i}}$ responses for leaves measured prior to harvest indicated maximum light- and $\mathrm{CO}_{2}$-saturated photosynthetic rates were about $30 \mu \mathrm{mol} \mathrm{m} \mathrm{m}^{-2} \mathrm{~s}^{-1}$, with the estimated maximum rate of RuBP carboxylation $\left(V_{\text {cmax }}\right)$ averaging $70 \mu \mathrm{mol}$ $\mathrm{m}^{-2} \mathrm{~s}^{-1}$ and the estimated maximum rate of RuBP regeneration $\left(J_{\max }\right)$ averaging $160 \mu \mathrm{mol} \mathrm{m} \mathrm{m}^{-2} \mathrm{~s}^{-1}$ (Fig. 3A). For leaves measured after the fruit were harvested, the typical $P_{\mathrm{N}} / C_{\mathrm{i}}$ response indicated a maximum photosynthetic rate of $25 \mu \mathrm{mol} \mathrm{m} \mathrm{m}^{-2} \mathrm{~s}^{-1}$ and $V_{\text {cmax }}$ averaged $50 \mu \mathrm{mol} \mathrm{m} \mathrm{m}^{-2} \mathrm{~s}^{-1}$ and $J_{\max }$ averaged $180 \mu \mathrm{mol} \mathrm{m} \mathrm{s}^{-2}$ (Fig. $3 B$ ).

Changes in $\boldsymbol{P}_{\mathrm{Nmax}}, \boldsymbol{V}_{\mathrm{cmax}}$, and $\boldsymbol{J}_{\max }$ over the growing season: The maximum $\mathrm{CO}_{2}$ - and light-saturated photosynthetic rates $\left(P_{\mathrm{Nmax}}\right)$ remained relatively high and more or less constant over the growing season, averaging $29.3 \mu \mathrm{mol}$ $\mathrm{m}^{-2} \mathrm{~s}^{-1}$ (Fig. 4A). However, just before harvest, the rates decreased to $23.8 \mu \mathrm{mol} \mathrm{m}^{-2} \mathrm{~s}^{-1}$. After harvest, $P_{\mathrm{Nmax}}$ initially remained low but within a few days recovered, with rates averaging $26.8 \mu \mathrm{mol} \mathrm{m}^{-2} \mathrm{~s}^{-1}$ until early autumn (Day 290) when the rates decreased again, probably in concert with decreased PFDs and temperatures (Fig. 4B). There was a significant effect of day on the $P_{\mathrm{Nmax}}$ but this accounted for less than $16 \%$ of the variance and there was no correlation with the seasonal climate. 


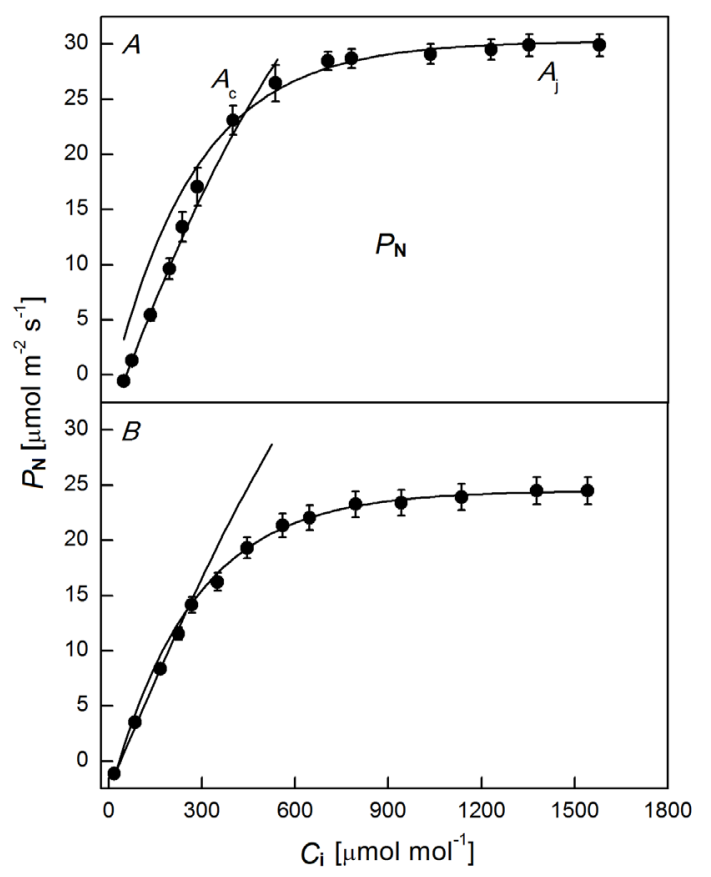

Fig. 3. Typical $P_{\mathrm{N}} / C_{\mathrm{i}}$ responses (mean $\pm \mathrm{SE}, n=3-4$ ) for Cox's Orange apple leaves before $(A)$ and after harvest $(B)$. Also shown are the modelled rates of RuBP carboxylation $\left(A_{\mathrm{c}}\right)$ and $\mathrm{RuBP}$ regeneration $\left(A_{\mathrm{j}}\right)$ as indicated and determined from fitting the $\mathrm{C}_{3}$ photosynthesis model of Farquhar et al. (1980) to these data.
At the start of measurements in late spring, the apparent $V_{\text {cmax }}$ was initially high at $84 \mu \mathrm{mol} \mathrm{m} \mathrm{m}^{-2} \mathrm{~s}^{-1}$ but declined slowly and then more rapidly by DAB 240, such that at harvest, the apparent rates were almost $80 \%$ lower at $20 \mu \mathrm{mol} \mathrm{m} \mathrm{m}^{-2} \mathrm{~s}^{-1}$ (Fig. 4C). After harvest, there was some initial recovery in $V_{\text {cmax }}$ to about half the spring rates but then a slow progressive decline in $V_{\text {cmax }}$ occurred for the remainder of the growing season (Fig. $4 D$ ). There was a significant effect of day on seasonal changes in $V_{\text {cmax }}$ and this accounted for about $60 \%$ of the variance, but there also some correlation with the seasonal climate, accounting for $35 \%$ of the variance.

By contrast, the apparent $J_{\max }$ initially increased slightly but then remained more or less constant at an average of $165 \mu \mathrm{mol} \mathrm{m} \mathrm{m}^{-2} \mathrm{~s}^{-1}$ until just before harvest, where the rates had declined by about $40 \%$ to $100 \mu \mathrm{mol} \mathrm{m}^{-2} \mathrm{~s}^{-1}$ (Fig. $4 E$ ). After harvest, there was also some recovery but, unlike $V_{\text {cmax }}, J_{\max }$ increased to rates higher than occurred in spring and peaked briefly at $200 \mu \mathrm{mol} \mathrm{m} \mathrm{m}^{-2} \mathrm{~s}^{-1}$ before slowly declining over the rest of the growing season, in keeping with $V_{\text {cmax }}$ (Fig. $4 F$ ). There was a significant effect of day on seasonal changes in $J_{\max }$ and this accounted for about $30 \%$ of the variance, but there was no correlation with the seasonal climate.

Stomatal limitation across the growing season: In late spring and early summer, there was a relatively high stomatal limitation at $45-60 \%$ but by mid to late summer,

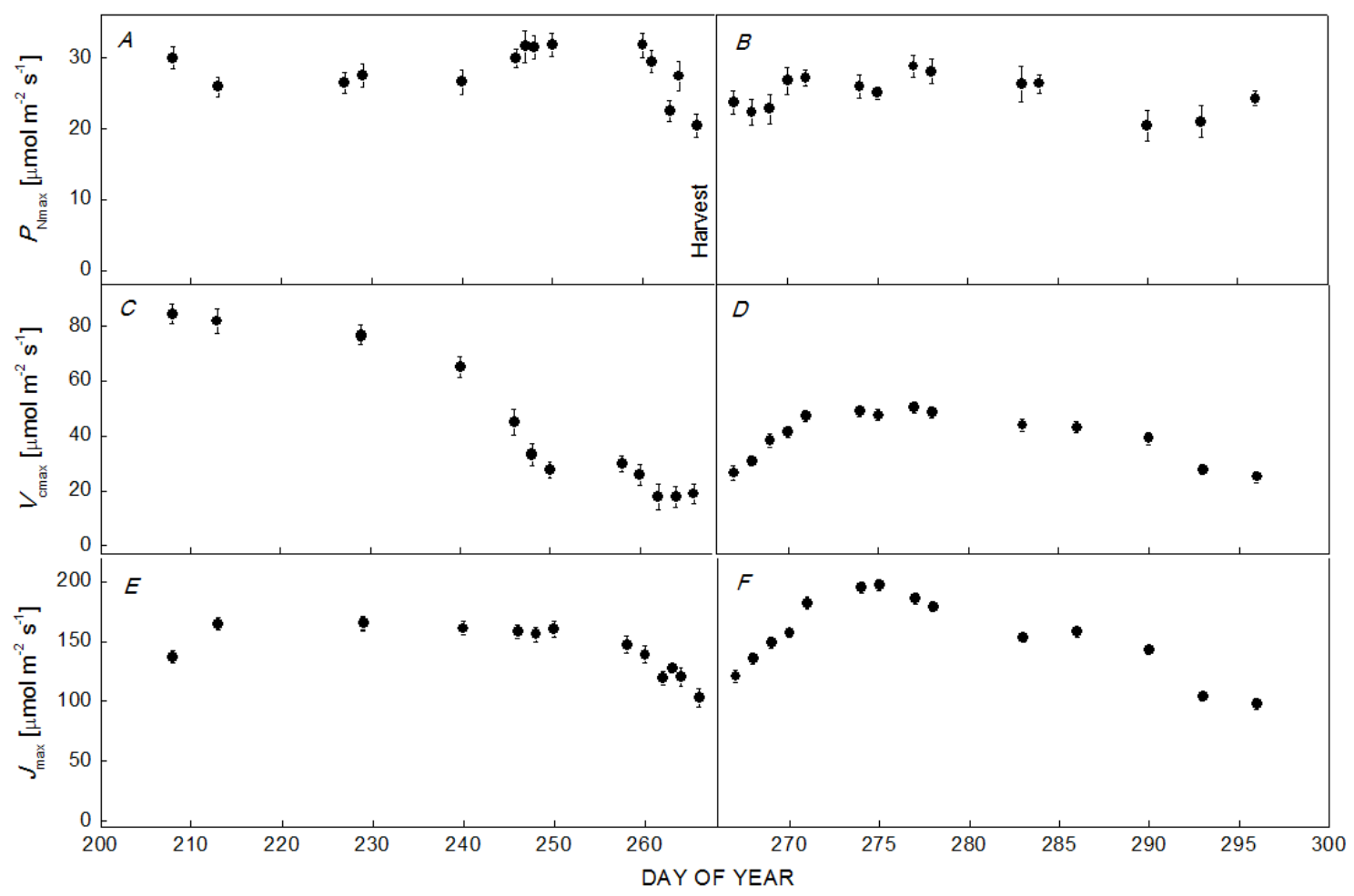

Fig. 4. Light and $\mathrm{CO}_{2}$-saturated maximum rates of photosynthesis $\left(P_{\mathrm{Nmax}}\right)$ of apple leaves of Cox's Orange apple trees growing in orchard conditions before $(A)$ and after $(B)$ harvest, estimated maximum rates of RuBP carboxylation $\left(V_{\text {cmax }}\right)$ before $(C)$ and after harvest $(D)$ and the estimated maximum rates of RuBP regeneration $\left(J_{\max }\right)$ before $(E)$ and after $(F)$ harvest. In all cases the values are means $\pm \mathrm{SE}$ $(n=9-12)$. Harvest occurred on Day 265 as indicated. 
the stomatal limitation had declined to between 30 and $45 \%$, consistent with the decrease in stomatal conductance (Fig. 5A,B). By contrast, after harvest the stomatal limitation decreased further to about $25 \%$ but thereafter, remained more or less constant.

\section{Discussion}

Across the growing season, rates of photosynthesis of the leaves of the cv. Cox's Orange apple trees at ambient conditions were relatively stable. This conforms to the PFDs remaining above about $900 \mu \mathrm{mol}$ (photon) $\mathrm{m}^{-2} \mathrm{~s}^{-1}$ (cf. Fig. 1) and seemingly high enough to maintain maximal rates (Greer 2018). Similarly, the maximum air temperatures remained mostly above about $20^{\circ} \mathrm{C}$ which might also explain the stability of the photosynthetic rates. However, rates of photosynthesis of leaves of cv. Braeburn apple trees were also relatively stable, apart from an early peak, from 25 to $158 \mathrm{~d}$ after flowering, the rates ranged from 9-12 $\mu \mathrm{mol} \mathrm{m}^{-2} \mathrm{~s}^{-1}$ (Palmer et al. 1997) as was also shown for this and two other cultivars (Palmer et al. 2002). Similarly, rates of photosynthesis of cv. Red Gala apple trees at a comparable temperature $\left(25^{\circ} \mathrm{C}\right)$ also indicated an initial early peak and thereafter ranged between 10.2 and $13.3 \mu \mathrm{mol} \mathrm{m}^{-2} \mathrm{~s}^{-1}$ from 53 to $160 \mathrm{DAB}$ (Greer 2015). Likewise, photosynthetic rates of cv. Starkrimson apple trees were also relatively stable across about $150 \mathrm{~d}$ of the growing season (Fujii and Kennedy 1985), similarly for cv. Golden Delicious and cv. Granny Smith (Mierowska et al. 2002). Thus, despite changes in the seasonal climate, most apple cultivars with a moderate crop load apparently maintained relatively stable rates of photosynthesis over the growing season.

As noted in this study, however, ambient rates of photosynthesis declined at or just before harvest and this was coincident with a marked reduction in stomatal conductance. However, the decrease was also coincident with PFDs declining to around $200 \mu \mathrm{mol} \mathrm{m} \mathrm{m}^{-2} \mathrm{~s}^{-1}$ and day temperatures declining to about $12^{\circ} \mathrm{C}$ and a night frost the day before harvest occurred ( $c f$. Fig. $1 B$ ). Thus, it seemed most likely that the low PFDs and temperatures were an explanation for the decrease in photosynthesis and perhaps also the decrease in stomatal conductance. Because the study was conducted in a commercial orchard, no fruit could be removed earlier than harvest to assess if these changes over harvest were more directly related to the fruit removal. Although the harvest date was not provided, Fujii and Kennedy (1985) also noted a marked decrease in photosynthesis occurred on cv. Starkrimson trees from about $164 \mathrm{DAB}$ and this was coincident with fruit dry matter stopping accumulation. However, this was not likely to be related to fruit growth because photosynthesis of fruiting and nonfruiting spurs declined in concert, suggesting leaf senescence and/or climate may have driven the decline. Few studies have determined photosynthesis as close to harvest as the present study, thus, it remains uncertain if rates of photosynthesis decline at this stage more generally.

It was, however, notable that the rates of photosynthesis of the Cox's Orange trees recovered relatively quickly after the fruit harvest, within $3 \mathrm{~d}$ rates were comparable with the pre-harvest rates and again remained reasonably steady thereafter. This increase in photosynthesis occurred despite the daily maximum PFDs declining markedly throughout this period and the maximum temperatures were falling as well, although no statistical correlations between photosynthesis and climate were observed. These data might suggest the current measurement conditions, saturating PFDs $\left(1,500 \mu \mathrm{mol} \mathrm{m} \mathrm{m}^{-2} \mathrm{~s}^{-1}\right)$ and leaf temperatures maintained around $20^{\circ} \mathrm{C}$, had a greater effect on rates of photosynthesis than the ambient conditions. However, while stomatal conductance declined prior to harvest, the conductance increased in the post-harvest period and remained reasonably high throughout and this probably accounted for the concurrent increase in transpiration. Thus, the stomatal conductance was unlikely to represent a major limitation to photosynthesis in the post-harvest period. Elsewhere, rates of light saturated photosynthesis measured $20 \mathrm{~d}$ after harvest of cv. Braeburn apple trees were also comparable with rates measured $30 \mathrm{~d}$ before harvest (Wünsche et al. 2000). However, in the same study, $48 \mathrm{~d}$ after harvest, the rates of photosynthesis had declined about $40 \%$ whereas in the present study $30 \mathrm{~d}$ after harvest, rates had declined about $25 \%$. In contrast, also for Braeburn apple trees $11 \mathrm{~d}$ after harvest, rates of photosynthesis had declined about $45 \%$ for high crop load trees but for trees with a low or no crop load, there was no change in the rates of photosynthesis (Palmer et al. 1997). In the Wünsche et al. (2000) study, $30 \mathrm{~d}$ after harvest, transpiration followed a similar trend to assimilation, declining by $40 \%$ in high cropped trees and no change in zero cropped trees compared with a $30 \%$ reduction in the

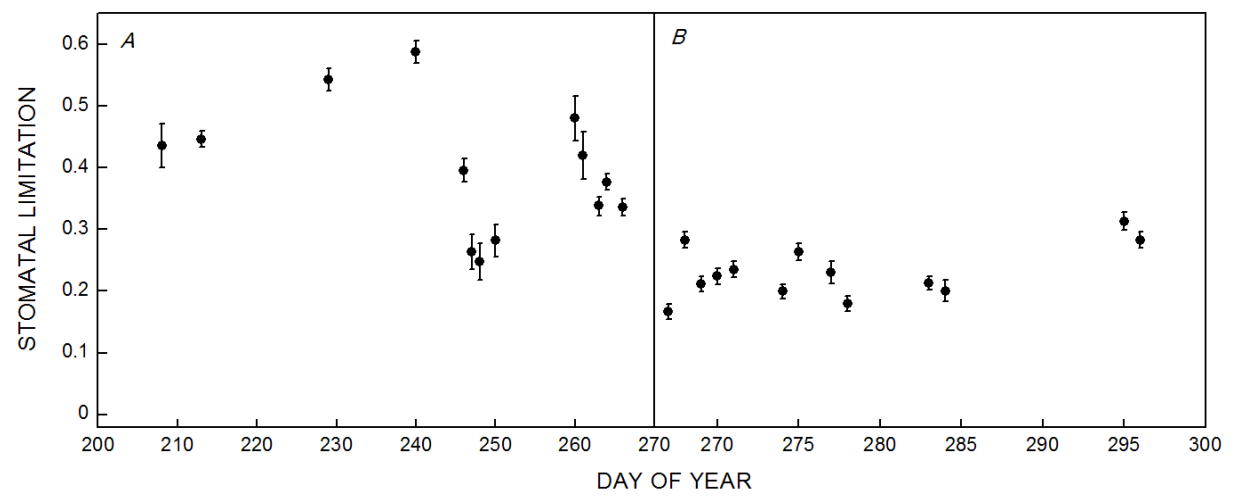

Fig. 5. Stomatal limitation of photosynthesis (mean $\pm \mathrm{SE}, n=9-12$ ) measured on leaves of Cox's Orange apple trees growing in orchard conditions before $(A)$ and after $(B)$ harvest. In each case, the values were determined from the $P_{\mathrm{N}} / C_{\mathrm{i}}$ curves according to the procedure of Farquhar and Sharkey (1982) and adopted by Greer and Weedon (2012). 
present study.

Saturating the photosynthetic process with substrate $\mathrm{CO}_{2}$ had no marked effect on the seasonal progression of $P_{\text {Nmax }}$ which essentially paralleled the rates at ambient conditions across the growing season ( $c f$. Figs. 2, 4). This maintenance of the $\mathrm{CO}_{2}$-saturated rates occurred despite a marked decrease in the apparent maximum rates of RuBP carboxylation and this suggested $V_{\text {cmax }}$ was not limiting photosynthesis at ambient and, therefore, also at saturating $\mathrm{CO}_{2}$ concentrations. By contrast, apparent maximum rates of RuBP regeneration across the growing season were in close accord with the rates of photosynthesis and hence were more likely to be limiting photosynthesis. Certainly, the decrease in $J_{\max }$ just before harvest was consistent with the decrease in photosynthesis then. By contrast after harvest, apparent rates of RuBP regeneration increased markedly and were highest across the whole growing season just $8 \mathrm{~d}$ after harvest. A concomitant increase in $\mathrm{CO}_{2}$-saturated rates of photosynthesis did not occur at this time which might, therefore, suggest that $J_{\max }$ was no longer limiting and perhaps the low rates of RuBP carboxylation might have become more limiting. However, as it were the rates of photosynthesis at the ambient $\mathrm{CO}_{2}$ concentration that increased most apparently immediately after harvest and both $V_{\text {cmax }}$ and $J_{\max }$ also increased in concert, therefore, any discrimination of the dominant limitation was not possible in that short time. Consistent with this, the seasonal changes in $P_{\mathrm{Nmax}}, V_{\mathrm{cmax}}$, and $J_{\max }$ for Quercus douglasii leaves also followed such similar patterns across the growing season although which factor that was most limiting to photosynthesis was not discernible $(\mathrm{Xu}$ and Baldocchi 2003).

Although the stomatal limitation of assimilation in the pre-harvest period was generally high early in the growing season and might have limited photosynthesis, the decrease later about $20 \mathrm{~d}$ before harvest did not comply with any change in photosynthesis so probably did not limit the process. A stronger but similar conclusion was reached in the post-harvest period when the stomatal limitation was low and relatively constant and, therefore, unlikely to limit photosynthesis much, in keeping with the conclusion about stomatal conductance.

Conclusions: Cox's Orange apple trees had relatively stable rates of photosynthesis across the growing season and appeared to be mostly limited by nonstomatal processes. Prior to harvest, photosynthesis appeared to be more limited by the regeneration of RuBP, as changes in $V_{\text {cmax }}$ had no apparent effect on the rates, whereas $J_{\max }$ appeared to mirror assimilation. But after harvest, apparent rates of carboxylation of RuBP were relatively low and appeared to be more limiting as $J_{\max }$ increased markedly and this change also had no apparent effect on photosynthesis. Perturbations in rates of photosynthesis in the few days before and after the harvest time also occurred in concert with changes in the stomatal conductance and $V_{\text {cmax }}$ and $J_{\max }$ and may have been as consequence of the removed crop load not demanding much assimilation from the trees but also this change could have been the result of mechanical effects on the trees in the process of harvesting the fruit. However, it was not possible to remove fruit in the trial so this hypothesis could not be sustained. In addition, the hypothesis that the loss of the fruit sink would cause a decrease in photosynthesis was also not sustained in this study.

\section{References}

Avery D.J.: Maximum photosynthetic rate - A case study in apple. - New Phytol. 78: 55-63, 1977.

Díaz-Espejo A., Walcroft A.S., Fernández J.E. et al.: Modeling photosynthesis in olive leaves under drought conditions. Tree Physiol. 26: 1445-1456, 2006.

Farquhar G.D., Sharkey T.D.: Stomatal conductance and photosynthesis. - Ann. Rev. Plant Physio. 33: 317-345, 1982.

Farquhar G.D., von Caemmerer S., Berry J.A.: A biochemical model of photosynthetic $\mathrm{CO}_{2}$ assimilation in leaves of $\mathrm{C}_{3}$ species. - Planta 149: 78-90, 1980.

Fujii J.A., Kennedy R.A.: Seasonal changes on the photosynthetic rates in apple trees. A comparison between fruiting and nonfruiting trees. - Plant Physiol. 78: 519-524, 1985.

Greer D.H.: Seasonal changes in the photosynthetic response to $\mathrm{CO}_{2}$ and temperature in apple (Malus domestica cv. 'Red Gala') leaves during a growing season with a high temperature event. - Funct. Plant Biol. 42: 309-324, 2015.

Greer D.H.: Modelling seasonal changes in the temperaturedependency of $\mathrm{CO}_{2}$ photosynthetic responses in two Vitis vinifera cultivars. - Funct. Plant Biol. 45: 315-327, 2017.

Greer D.H.: Photosynthetic light responses of apple (Malus domestica Borkh.) in relation to leaf temperature, $\mathrm{CO}_{2}$ and leaf nitrogen on trees grown in orchard conditions. - Funct. Plant Biol. 45: 1149-1161, 2018.

Greer D.H., Weedon M.M.: Modelling photosynthetic responses to temperature of grapevine (Vitis vinifera cv. Semillon) leaves on vines grown in a hot climate. - Plant Cell. Environ. 35: 1050-1064, 2012.

Greer D.H., Wünsche J.N., Halligan E.A.: Influence of postharvest temperatures on leaf gas exchange, carbohydrate reserves and allocations, subsequent budbreak, and fruit yield of 'Braeburn' apple (Malus domestica) trees. - New Zeal. J. Crop Hort. 30: 175-185, 2002.

Gucci R., Corelli Grappadelli L., Tustin D.S., Ravaglia G.: The effects of defruiting at different stages of fruit development in leaf photosynthesis of 'Golden delicious' apple. - Tree Physiol. 15: 35-40, 1995.

Herold A.: Regulation of photosynthesis by sink activity - the missing link. - New Phytol. 86: 131-144, 1980.

Holzapfel B., Smith J.P., Field S.K., Hardie J.: Dynamics of carbohydrate reserves in cultivated grapevines. - Hortic. Rev. 37: 143-211, 2010.

Jones H.G.: Partitioning stomatal and non-stomatal limitations to photosynthesis. - Plant Cell Environ. 8: 95-104, 1985.

Juárez-López F.J., Escudero A., Mediavilla S.: Ontogenetic changes in stomatal and biochemical limitations to photosynthesis of two co-occurring Mediterranean oaks differing in leaf life span. - Tree Physiol. 28: 367-374, 2008.

Kandiah S.: Turnover of carbohydrates in relation to growth in apple trees. II. Distribution of ${ }^{14} \mathrm{C}$ assimilates labelled in autumn, spring and summer. - Ann. Bot.-London 44: 185-195, 1979.

Le Roux X., Grand S., Dreyer E., Daudet F.A.: Parameterization and testing of a biochemically based photosynthesis model for walnut (Juglans regia) trees and seedlings. - Tree Physiol. 19: 481-492, 1999.

Lin Y.-S., Medlyn B.E., Ellsworth D.S.: Temperature responses 
of leaf net photosynthesis: The role of component processes. Tree Physiol. 32: 219-231, 2012.

Medlyn B.E., Loustau D., Delzon S.: Temperature response of parameters of a biochemically based model of photosynthesis. I. Seasonal changes in mature maritime pine (Pinus pinaster Ait). - Plant Cell Environ. 25: 1155-1165, 2002.

Mierowska A., Keutgen N., Huysamer M., Smith V.: Photosynthetic acclimation of apple spur leaves to summer-pruning. Sci. Hortic.-Amsterdam 92: 9-27, 2002.

Misson L., Tu K.P., Boniello R.A., Goldstein A.H.: Seasonality of photosynthetic parameters in a multi-specific and vertically complex forest ecosystem in the Sierra Nevada of California. Tree Physiol. 26: 729-741, 2006.

Nebauer S.G., Arenas C., Rodríguez-Gamir J. et al.: Crop load does not increase the photosynthetic rate in Citrus leaves under regular cropping conditions. A study throughout the year. - Sci. Hortic.-Amsterdam 160: 358-365, 2013.

Palmer J.W., Giuliani R., Adams H.M.: Effect of crop load on fruiting and leaf photosynthesis of 'Braeburn'/M.26 apple trees. - Tree Physiol. 17: 741-746, 1997.

Palmer J.W., Wünsche J.N., Meland M., Han A.: Annual drymatter production by three apple cultivars at four within-row spacings in New Zealand. - J. Hortic. Sci. Biotech. 77: 712-717, 2002.

Quentin A.G., Close D.C., Hennen L.M., Pinkard E.A.: Downregulation of photosynthesis following girdling, but contrasting effects on fruit set and retention, in two sweet cherry cultivars. - Plant Physiol. Bioch. 73: 359-367, 2013.

Ribeiro R.V., Machado E.C., Santos M.G., Oliveira R.F.: Seasonal and diurnal changes in photosynthetic limitation of young sweet orange trees. - Environ. Exp. Bot. 66: 203-211, 2009.

Rosati A., Esparza G., DeJong T.M., Pearcy R.W.: Influence of canopy light environment and nitrogen availability on leaf photosynthetic characteristics and photosynthetic nitrogen-use efficiency of field-grown nectarine trees. - Tree Physiol. 19:
173-180, 1999.

Schultz H.R.: Extension of a Farquhar model for limitations of leaf photosynthesis induced by light environment, phenology and leaf age in grapevines (Vitis vinifera L. cvv. White Riesling and Zinfandel). - Funct. Plant Biol. 30: 673-687, 2003.

Schultz H.R., Kiefer W., Gruppe W.: Photosynthetic duration, carboxylation efficiency and stomatal limitation of sun and shade leaves of different ages in field-grown grapevine, Vitis vinifera L. - Vitis 35: 169-176, 1996.

Sharkey T.D., Bernacchi C.J., Farquhar G.D., Singsaas E.L.: Fitting photosynthetic carbon dioxide response curves for $\mathrm{C}_{3}$ leaves. - Plant Cell Environ. 30: 1035-1040, 2007.

Silim S.N., Ryan N., Kubien D.S.: Temperature responses of photosynthesis and respiration in Populus balsamifera L.: acclimation versus adaptation. - Photosynth. Res. 104: 19-30, 2010.

Walcroft A., Le Roux X., Diaz-Espejo A. et al.: Effects of crown development on leaf irradiance, leaf morphology and photosynthetic capacity in a peach tree. - Tree Physiol. 22: 929-938, 2002.

Wibbe M.L., Blanke M.M.: Effects of defruiting on source-sink relationship, carbon budget, leaf carbohydrate content and water use efficiency of apple trees. - Physiol. Plantarum 94: 529-533, 1995.

Wibbe M.L., Blanke M.M.: Effect of fruiting and drought or flooding on carbon balances of apple trees. - Photosynthetica 33: 269-275, 1997.

Wünsche J.N., Palmer J.W., Greer D.H.: Effects of crop load on fruiting and gas-exchange characteristics of 'Braeburn'/M.26 apple trees at full canopy. - J. Am. Soc. Hortic. Sci. 125: 93-99, 2000.

Xu L., Baldocchi D.: Seasonal trends in photosynthetic parameters and stomatal conducatance of blue oak (Quercus douglassi) under prolonged summar drought and high temperature. Tree Physiol. 23: 865-877, 2003.

(C) The authors. This is an open access article distributed under the terms of the Creative Commons BY-NC-ND Licence. 